\title{
Parvalbumin loss following chronic sub-anesthetic NMDA antagonist treatment is age-dependent in the hippocampus: Implications for modeling NMDA hypofunction
}

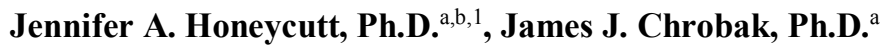 \\ ${ }^{a}$ Department of Psychology, Division of Behavioral Neuroscience, 406 Babbidge Road Unit 1020, University of Connecticut, \\ Storrs, CT 06296 USA \\ ${ }^{\mathrm{b}}$ Department of Psychology, 360 Huntington Ave NI 125, Northeastern University, Boston, MA 02115 USA
}

${ }^{1}$ Correspondence: J.Honeycutt@NEU.edu, (617) 373-3982

\begin{abstract}
A marked decrease in parvalbumin (PV), a calcium-binding protein specific to a subset of GABAergic neurons, is a consistent finding in postmortem schizophrenic brain tissue. This reduction is selective to PV and is regionally specific: occurring primarily in the prefrontal cortex and hippocampus (HPC) of patients. Rodent models of NMDA receptor hypofunction utilizing NMDA antagonist treatments - e.g. ketamine (KET) - show schizophrenia-like cognitive and behavioral impairments with parallel changes in PV. While decreased PV is considered a hallmark of neuropathology in schizophrenia, previous work elucidating the effects of KET administration on PV are contradictory, with findings suggesting decreased, increased, or no change in PV expression. Upon close examination of the procedures used across studies, there are two primary inconsistencies, including: 1) the age of animals used; and 2) the timeline of post-treatment tissue collection. To better understand whether these key differences impact observed PV changes, the present study investigated the impact of age and time of sacrifice on chronic KET-induced PV changes in the neocortex and HPC. Our findings suggest an effect of age, but not sacrifice timeline, on PV cell count following 14 days of subanesthetic KET treatment. We provide evidence that 1-month-old rats exhibit significant KET-induced HPC PV decreases, while adult rats show a modest increase in HPC PV following chronic KET. Taken together, we propose that PV is a dynamic marker, and that changes in cell counts - and their interpretation - following NDMA antagonist treatment should be considered in the context of age.
\end{abstract}

Keywords: Parvalbumin, Ketamine, NMDA Hypofunction, Hippocampus, Schizophrenia, Development

\section{Introduction}

Investigations into the neuropathology of schizophrenia in patient postmortem brain tissue have revealed abnormalities in neuroanatomical structure and changes in biological markers of distinct neural populations (Eyles et al., 2002). These observed abnormalities have given us a glimpse of putative mechanisms that may underlie the pervasive cognitive and behavioral changes characteristic of schizophrenia. Furthermore, these findings have allowed for the advancement of rodent modeling techniques, which have become integral to our ability to systematically study possible factors contributing to neural and behavioral pathological phenotypes. Specifically, postmortem findings reliably point to a selective decrease in the calcium-binding protein parvalbumin (PV) exclusively within the prefrontal cortex (PFC; Beasley and Reynolds, 1997) and hippocampus (HPC; Zhang and Reynolds, 2002). In the rodent literature, models employing N-methyl-D-aspartate (NMDA) antagonist treatments (e.g. ketamine (KET); MK-801), as a means of inducing a state of NMDA receptor hypofunction, are widely accepted and used in large part for their ability to replicate cognitive and behavioral dysfunction seen in schizophrenia (Meltzer et al., 2011; Coyle et al., 2012; Meltzer et al., 2013). Importantly, NMDA antagonist treatments in rodents have been shown to replicate the robust and specific decrease in PV expression seen in schizophrenic patients within the HPC and PFC (Reynolds et al., 2004; Adell et al., 2012; Gonzalez-Burgos and Lewis, 2012). However, despite general agreement that decreased PV expression (via protein levels and/or cell counts) following pharmacologically-induced NMDA hypofunction is a valid model of schizophrenic neuropathology, there exists a growing number of studies presenting conflicting findings, calling into question the aptness of utilizing PV as a marker of pathology across development.

Within the literature, discrepancies regarding the outcomes of NMDA antagonism on neuropathology, particularly on PV, are apparent with some groups indicating decreases in PV following treatment (e.g., Keilhoff et al., 2004a; Keilhoff et al., 2004b; Behrens et al., 2007; Braun et al., 2007; Wang et al., 2008; Zhang et al., 2008; Rómon et al., 2011; Kittelberger et al. 2012), while others report no change following treatment (e.g., Rujescu et al., 2005; Benneyworth et al., 2011). These conflicting findings raise questions regarding the methodological preparations employed, as well as the translational validity of the findings. Interestingly, upon examination of the methods used across various studies, critical differences in methodology exist including: 1) NMDA antagonist treatment regimen; 2) the age of the subjects; 3) whether or not subjects are behaviorally naïve; and 4) the timeline of brain tissue collection following the cessation of treatment and/or behavioral assays (for a more comprehensive list of previous findings with detailed methods (i.e. age, treatment regimen, sacrifice timeline, etc.) see Table 1). Indeed, the lack of continuity and comprehensive rationale in the age of subjects used across studies points to an underlying assumption of stability in PV phenotype over the lifespan, which may prove problematic when trying to translate findings to additional populations of interest.

Findings indicating developmental changes in PV from young to adult rodents provide a compelling argument for considering age as a factor. Specifically, our group and others have presented evidence of decreased PV within the HPC in adult compared to young rodents (de Jong et al., 1996; Honeycutt et al., 2016). These findings indicate a 
bioRxiv preprint doi: https://doi.org/10.1101/399188; this version posted August 23, 2018. The copyright holder for this preprint (which was not certified by peer review) is the author/funder, who has granted bioRxiv a license to display the preprint in perpetuity. It is made available under aCC-BY-NC-ND 4.0 International license.

Honeycutt \& Chrobak, 08.23.2018 - preprint copy - BioRxiv

distinct developmental trajectory of PV phenotype which likely influences the efficacy and/or outcomes of experimental treatments based on subject age. In addition to age mediating PV outcomes across studies, there is evidence that behavioral and cognitive training/testing may also serve to alter PV across multiple brain regions (e.g., Gomes da Silva et al., 2010; Urakawa et al., 2013). Thus, it is necessary to determine the baseline effect of pharmacological models in the absence of behavioral manipulations to obtain a clear understanding of the effect of the KET model in isolation. In addition to these possible mediating factors, time of tissue collection - with respect to cessation of treatment - may be a significant mediator of PV findings, as work by Behrens and colleagues (2008) suggests that PV phenotype may recover as a function of time post treatment. These factors, which have been largely overlooked as a significant driving influence in PV changes following NMDA antagonist treatment, may provide key insights into the dynamic nature of PV and elucidate its relationship to pathology in schizophrenia.

A more thorough understanding of the normative relationship between PV and these possible mitigating factors is warranted, thus the present work sought to investigate: 1) age-dependent changes in PV across development in behaviorally naïve rats; 2) the neural consequences of chronic KET administration on PV as a function of age; and 3) the role of tissue collection timeline post KET cessation on PV cell counts in key brain regions known to be selectively impacted in schizophrenia. Here, we provide evidence suggesting a differential effect of chronic KET administration as a function of age, such that 1 - monthold rats show a significant decrease in PV, whereas 6-month-old rats show a pattern of increased PV within the HPC. To our knowledge, this is the first report detailing a distinct and opposite pattern of PV+ cell counts within the HPC following chronic KET treatment in an agedependent manner. Taken together, these findings provide important insight into the need to carefully consider stage of development in rodent models of pathology.

\section{Methods}

\section{Subjects and drug administration}

Subjects were male Sprague-Dawley rats $(n=30)$ sourced from Charles River Laboratories (Wilmington, MA) and aged either $1(n=15)$ or 6 months $(n=15)$. Prior to pharmacological manipulations, rats were individually housed in polycarbonate caging with free access to food and water and were allowed 1 week to acclimate to the colony room. All rats were housed in a temperature and humidity-controlled vivarium with a 12-hour light/dark cycle (lights on at 08:00h) and exposed to normal weekly husbandry procedures but were otherwise behaviorally naïve. Subsets of rats from each age group were assigned to one of 3 treatment groups: 1) chronic KET regimen with brain tissue collection immediately following treatment cessation (KET-I; $30 \mathrm{mg} / \mathrm{kg} \mathrm{IP} ; n=5$ per age group); 2) chronic KET regimen with tissue collection delayed 10 days post treatment cessation (KET-D; $30 \mathrm{mg} / \mathrm{kg}$ IP; $n=5$ per age group); or 3) comparable control with IP injection of physiological saline (CON; $n=5$ per age group). Chronic KET administration was sub-anesthetic and lasted for 14 consecutive days (see Figure 1A for experimental timeline). Importantly, the chronic KET regimen did not impact the overall health of the animals, as evidenced by no significant weight changes between groups across treatment days (data not shown). The KET dose of 30 $\mathrm{mg} / \mathrm{kg}$ was chosen based on the frequency with which it is used in the literature by many research groups as a sub-anesthetic acute and/or chronic treatment model of NMDA hypofunction (see Table 1). All housing and experimental procedures were performed in accordance with, and approved by, the University of Connecticut Institutional Animal Care and Use Committee. See Figure 1A for a methodological timeline.

\section{Tissue Collection \& Immunohistochemistry}

Following treatment cessation and experimental timeline, rats were anesthetized with Euthasol (pentobarbital solution; 0.5-1.0mL delivered IP) and transcardially perfused with ice-cold $0.9 \%$ physiological saline solution immediately followed by ice-cold $3.7 \%$ paraformaldehyde

A
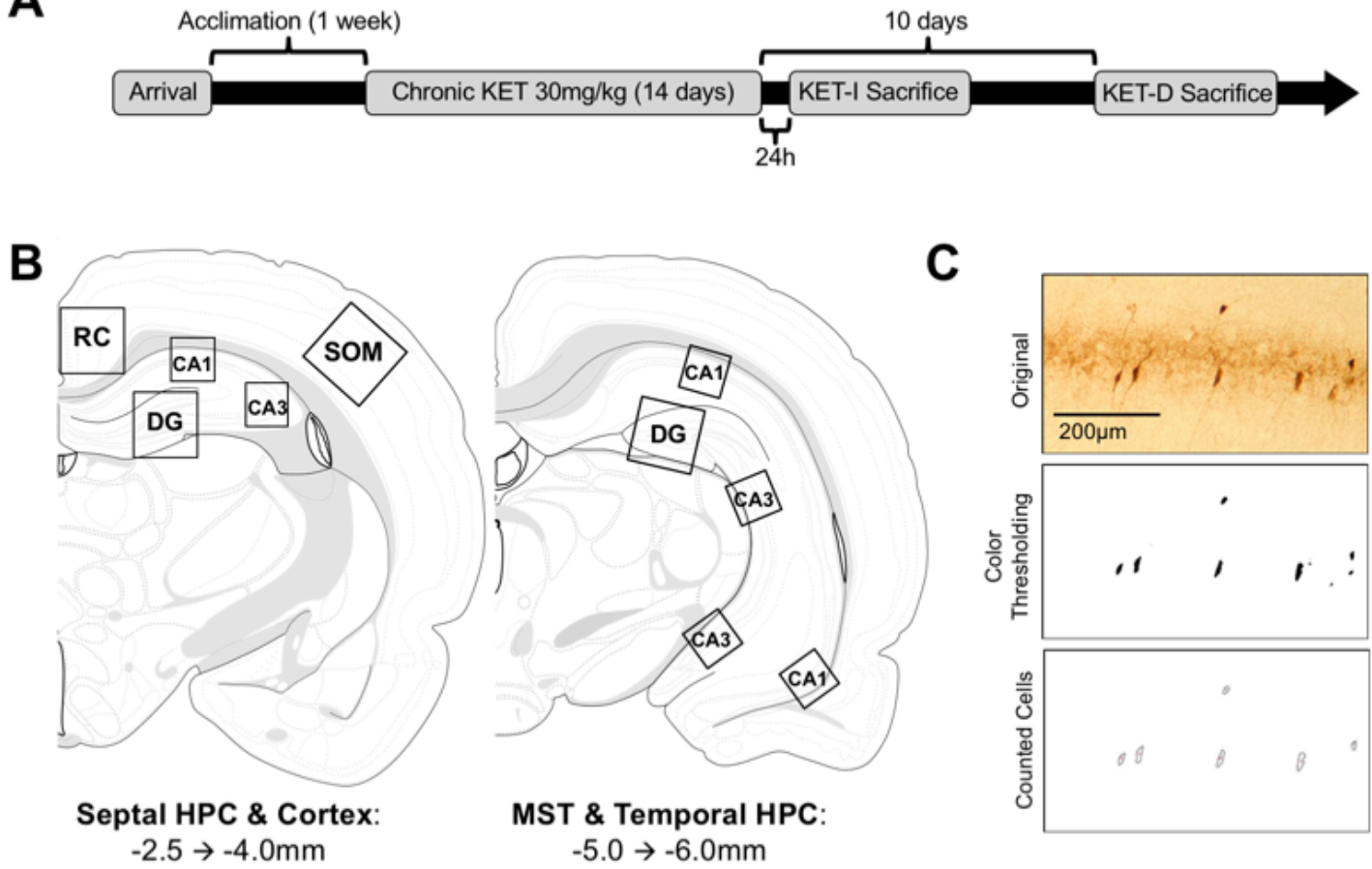

Figure 1. Experimental Methods: Methodological timeline of experiment (A). After a one-week acclimation rats began chronic treatment (either $30 \mathrm{mg} / \mathrm{kg} \mathrm{KET}$ or saline CON, IP) for 14 consecutive days. Rats were then sacrificed either 24 hours (KET-I) or 10 days (KET-D) following treatment cessation. Sampling regions (B) included regions encompassing the retrosplenial cortex (RC), Somatosensory Barrel Fields (SOM), and HPC sub-regions (CA1, CA3, DG) across the septotemporal axis. An example of $\mathrm{PV}+$ cell quantification within $\mathrm{HPC}$ CA1 can be seen in (C). The top panel shows an original photomicrograph with darkly stained PV+ cells. The center panel shows the same photomicrograph thresholded based on color density to isolate the most darkly stained cells. A macro as run to quantify the number of $\mathrm{PV}+$ cells while excluding non-cell artifacts, with the output indicating counted cells shown in the bottom panel. All anatomical measurements are relative to Bregma. Atlas adapted from Swanson (2004). 
bioRxiv preprint doi: https://doi.org/10.1101/399188; this version posted August 23, 2018. The copyright holder for this preprint (which was not certified by peer review) is the author/funder, who has granted bioRxiv a license to display the preprint in perpetuity. It is made available under aCC-BY-NC-ND 4.0 International license.

Honeycutt \& Chrobak, 08.23.2018 - preprint copy - BioRxiv

Table 1.

Previous work detailing changes in PV pathology following NMDA antagonist treatment

\begin{tabular}{|c|c|c|c|c|c|c|c|c|}
\hline Study & Species & Age & Drug & $\begin{array}{l}\text { Treatment } \\
\text { Regimen }\end{array}$ & $\begin{array}{l}\text { Timeline: } \\
\text { Post- } \\
\text { Cessation }\end{array}$ & $\begin{array}{l}\text { Quant. } \\
\text { Method }\end{array}$ & \multicolumn{2}{|c|}{ PV Results } \\
\hline & & & & & & & HPC & PFC \\
\hline $\begin{array}{l}\text { Abdul-Monim } \\
\text { et al., } 2007\end{array}$ & Rat (f) & $\begin{array}{l}\text { Not specified } \\
\text { (approx. }>5 \mathrm{mo})\end{array}$ & $\mathrm{PCP}$ & $\begin{array}{l}2 \mathrm{mg} / \mathrm{kg}(2 \mathrm{x} / \mathrm{d}) \times 7 \\
\text { days }\end{array}$ & 42 days & $\mathrm{IHC}$ & $\downarrow(\mathrm{CA} 3, \mathrm{DG})$ & $\begin{array}{l}\downarrow(\mathrm{M} 1) \\
\uparrow(\mathrm{M} 2 ; \mathrm{CG})\end{array}$ \\
\hline $\begin{array}{l}\text { Behrens et al., } \\
2007\end{array}$ & $\begin{array}{l}\text { Mouse } \\
(\mathrm{m})\end{array}$ & Not specified & KET & $30 \mathrm{mg} / \mathrm{kg}$ (IP) $\times 2$ days & 18 hours & $\mathrm{IHC}$ & -- & $\downarrow$ \\
\hline $\begin{array}{l}\text { Behrens et al., } \\
2008\end{array}$ & $\begin{array}{l}\text { Mouse } \\
(\mathrm{m})\end{array}$ & $12-15$ weeks & KET & $\begin{array}{l}30 \mathrm{mg} / \mathrm{kg}(\mathrm{IP}) \times 1 \text { or } 2 \\
\text { days }\end{array}$ & $\begin{array}{l}1,3, \text { or } 10 \\
\text { days }\end{array}$ & $\mathrm{IHC}$ & -- & $\begin{array}{l}\text { n.c. }(1 \mathrm{~d}) \\
\downarrow(2 \mathrm{~d})\end{array}$ \\
\hline \multirow[t]{2}{*}{$\begin{array}{l}\text { Benneyworth et } \\
\text { al., } 2011\end{array}$} & Rat (m) & Not specified & KET & $30 \mathrm{mg} / \mathrm{kg}$ (IP) x 5 days & 72 hours & $\begin{array}{l}\text { IHC; } \\
\text { WB }\end{array}$ & n.c. & n.c. \\
\hline & $\begin{array}{l}\text { Mouse } \\
(\mathrm{m})\end{array}$ & 9-13 weeks & $\begin{array}{l}\text { KET or } \\
\text { PCP }\end{array}$ & $\begin{array}{l}30 \mathrm{mg} / \mathrm{kg} \text { (IP) } \times 5 \text { days } \\
6 \mathrm{mg} / \mathrm{kg} \text { (IP) } \times 5 \text { days }\end{array}$ & 72 hours & $\begin{array}{l}\text { IHC; } \\
\text { WB }\end{array}$ & n.c. & n.c. \\
\hline $\begin{array}{l}\text { Braun et al., } \\
2007\end{array}$ & Rat (m) & $\begin{array}{l}\text { Approx. } 35 \\
\text { days }\end{array}$ & MK-801 & $\begin{array}{l}.02 \mathrm{mg} / \mathrm{kg}(\mathrm{IP}) \times 21 \\
\text { days }\end{array}$ & 24 hours & $\mathrm{IHC}$ & $\downarrow(\mathrm{CA} 1, \mathrm{DG})$ & n.c. \\
\hline $\begin{array}{l}\text { Jeevakumar et } \\
\text { al., } 2015\end{array}$ & $\begin{array}{l}\text { Mouse } \\
(\mathrm{m})\end{array}$ & 1-17 weeks & KET & $\begin{array}{l}30 \mathrm{mg} / \mathrm{kg}(\mathrm{SC}) \text { on } \\
\text { PD } 7,9,11\end{array}$ & 16 weeks & $\mathrm{IHC}$ & -- & $\downarrow$ \\
\hline $\begin{array}{l}\text { Jenkins et al., } \\
2010\end{array}$ & Rat (m) & Not specified & $\mathrm{PCP}$ & $\begin{array}{l}2 \text { or } 5 \mathrm{mg} / \mathrm{kg}(\mathrm{IP}) \times 7 \\
\text { days }\end{array}$ & 42 days & $\mathrm{IHC}$ & $\downarrow(\mathrm{CA} 1, \mathrm{CA} 3)$ & -- \\
\hline $\begin{array}{l}\text { Keilhoff et al., } \\
2004\end{array}$ & Rat (m) & 8 weeks & KET & $30 \mathrm{mg} / \mathrm{kg}$ (IP) x 5 days & 14 days & $\mathrm{IHC}$ & $\begin{array}{l}\downarrow(\mathrm{CA} 1, \mathrm{CA} 3, \\
\mathrm{DG})\end{array}$ & -- \\
\hline $\begin{array}{l}\text { Kittelberger et } \\
\text { al.,2012 }\end{array}$ & Rat (m) & $\begin{array}{l}\text { Adult (age not } \\
\text { specified) }\end{array}$ & KET & $30 \mathrm{mg} / \mathrm{kg}$ (IP) x 5 days & 2-4 weeks & $\mathrm{IHC}$ & $\downarrow(\mathrm{CA} 1, \mathrm{CA} 3)$ & -- \\
\hline Koh et al., 2016 & $\begin{array}{l}\text { Mouse } \\
(\mathrm{m})\end{array}$ & $1-6$ months & KET & $\begin{array}{l}16 \mathrm{mg} / \mathrm{kg}(\mathrm{SC}) \mathrm{x} 1 \\
\text { month }(3 \mathrm{x} / \text { week })\end{array}$ & 3-5 months & $\mathrm{IHC}$ & $\downarrow(\mathrm{CA} 1)$ & n.c. \\
\hline $\begin{array}{l}\text { Rujescu et al., } \\
2005\end{array}$ & Rat (m) & $32-40$ days & MK-801 & $\begin{array}{l}.02 \mathrm{mg} / \mathrm{kg}(\mathrm{IP}) \times 14 \\
\text { days }\end{array}$ & 24 hours & $\mathrm{IHC}$ & $\begin{array}{l}\downarrow(\text { HPC total }) \\
\text { n.c. (CA1, } \\
\text { CA3, DG) }\end{array}$ & -- \\
\hline $\begin{array}{l}\text { Schobel et al., } \\
2013\end{array}$ & $\begin{array}{l}\text { Mouse } \\
(\mathrm{m})\end{array}$ & $65-75$ days & KET & $\begin{array}{l}16 \mathrm{mg} / \mathrm{kg}(\mathrm{IP}) \times 1 \\
\text { month }(3 \mathrm{x} / \mathrm{wk})\end{array}$ & 48 hours & $\mathrm{IHC}$ & $\downarrow$ (CA fields $)$ & -- \\
\hline
\end{tabular}

Previous work evaluating the impact of acute and/or chronic NMDA antagonism varies widely in methodologies utilized, particularly with regard to length and dose of treatment, age of subjects, amount of time between treatment-cessation and tissue collection. These discrepancies likely contribute to variability between studies and research groups.

Abbreviations: $\downarrow$, decrease from CON; $\uparrow$, increase from CON; n.c., no change from CON; f, female; m, male; PD, Postnatal Day; IHC, Immunohistochemistry; WB, Western Blot; M1, Primary Motor Cortex; M2, Secondary Motor Cortex; CG, Cingulate Cortex; IP, Intraperitoneal Injection; SC, Subcutaneous Injection

solution. Brains were removed and individually stored in 3.7\% paraformaldehyde solution for 1 week. Prior to sectioning, brains were transferred into a $30 \%$ sucrose solution for cryoprotection. All brains were coronally sliced into $60 \mu \mathrm{m}$ serial sections on a cryostat and stored in phosphate-buffered saline (PBS)-containing well plates prior to immunohistochemical procedures.

One series of tissue from each brain was selected to examine PV immunoreactivity (distance per analyzed slice approx. $360 \mu \mathrm{m}$ ), with sections encompassing tissue approximately $-2.5 \mathrm{~mm}$ through $-6 \mathrm{~mm}$ relative to Bregma to include the septotemporal extent of the HPC, as well as adjacent cortical regions (retrosplenial and somatosensory cortices; Paxinos and Watson, 1997). Free-floating sections were initially blocked in 5\% normal goat serum (NGS; Jackson Immuno), $0.1 \%$ triton$\mathrm{X}$, and PBS solution for 1 hour, followed by 3 five-minute washes in PBS. Sections were transferred to primary antibody solution $(1: 16,000$ rabbit anti-parvalbumin polyclonal (ABCAM), $0.1 \%$ triton-X, and PBS) for a 1-hour incubation at room temperature. Sections were rinsed in PBS and transferred to secondary solution (horseradish peroxidase (HRP) labeled polymer anti-rabbit; DAKO) for 1 hour at room temperature. Following a final set of washes in PBS, sections were transferred into a diaminobenzidine (DAB) chromogen solution (DAKO) for ten minutes to develop the stain. Sections were mounted and dried on glass slides before being cover-slipped for microscopy. Adjacent sections were stained with Nissl to assist in the identification of each region of interest.

\section{Quantification of PV cell counts}

Slides containing tissue processed for PV immunoreactivity were analyzed using a Nikon Eclipse E600 (Melville, NY) upright microscope equipped with an Insight SPOT digital camera (Diagnostic Instruments, Inc.). Photomicrographs of regions of interest including: retrosplenial 
bioRxiv preprint doi: https://doi.org/10.1101/399188; this version posted August 23, 2018. The copyright holder for this preprint (which was not certified by peer review) is the author/funder, who has granted bioRxiv a license to display the preprint in perpetuity. It is made available under aCC-BY-NC-ND 4.0 International license.

Honeycutt \& Chrobak, 08.23.2018 - preprint copy - BioRxiv

cortex, somatosensory barrel fields, and HPC (including CA1, CA3, and DG sub-divisions; as sampled in Nomura et al., 1997 and Honeycutt et al., 2016), were catalogued and stored digitally for analysis by a researcher blind to treatment and age. For additional sampling and analysis parameters, see previously reported methods from our group (Honeycutt et al., 2016) and Figure1B for schematic of counting regions. To ensure precision in the quantification of PV-expressing cells within each region of interest photomicrographs were taken at either 20x magnification (CA1, CA3) or 10x magnification (cortical areas, DG). Digital photomicrographs were analyzed using ImageJ software $(\mathrm{NIH})$, and the number of PV-immunoreactive cells were quantified using macros written to automate counting for each region and calculate the number of PV+ cells based on color density to isolate the most darkly stained cells, and to exclude any thresholded particles (e.g. non-cell artifacts) that did not meet criteria for inclusion (i.e. size, sphericity). A representative example of cell identification/counting using color thresholding can be seen in Figure 1C. This methodology to quantify PV as cell counts using ImageJ (as opposed to stereology) was carefully selected to address the fact that PV cells have a non-uniform distribution, particularly within the HPC and neocortex (Benes and Lange, 2001; Guillery, 2002). The sizes of the analyzed regions were as follows: HPC CA1/CA 3 - $800 \mu \mathrm{m}^{2}$; HPC DG and cortical areas - $1600 \mu \mathrm{m}^{2}$. The average number of PV cells for HPC CA1 and CA3 were normalized to represent the average number of PV-positive cells per $1600 \mu \mathrm{m}^{2}$ for cross regional comparisons and consistency across data sets.

\section{Statistical analysis of PV cell count}

To characterize the differences in PV+ cell counts within specified regions of interest based on treatment and time of sacrifice, the average number of PV expressing cells within each photomicrograph was calculated using ImageJ, and group means were computed. This was done across brain regions for each rat, and for each region of interest the average number of PV cells was computed from 3-6 photomicrographs per region (2-3 from each of the left and right hemispheres). Data was collapsed across hemisphere for all brain regions, as there were no significant hemispheric differences in PV count. A two-way ANOVA (Treatment (CON, KET-I, KET-D) x Age $(1 \mathrm{mo}, 6 \mathrm{mo})$ was conducted for each neocortical region to determine differences based on age and/or treatment and followed up with Holm-Sidak's post-hoc analyses with corrections for multiple comparisons.

Within the HPC sub-regions (CA1, CA3, DG) averages for septotemporal regions (septal, midseptotemporal, temporal) were considered individual samples and contributed to overall averages for respective regions, such that each group's sub-region average was comprised of 10 (DG) to 15 (CA1, CA3) data points. Differences in PV cell counts were assessed using separate two-way ANOVA analyses (Treatment (CON, KET-I, KET-D) x Age $(1 \mathrm{mo}, 6 \mathrm{mo})$ for each subregion to determine whether there were changes within each group as a function of treatment and/or age. Significant effects were followed up with Holm-Sidak's post-hoc analyses with corrections for multiple comparisons.

\section{Results}

\section{Hippocampal findings}

\section{Age-dependent $P V$ cell counts in CON groups}

In the HPC there were significant main effects of age $(F(1,74)=$ $24.07, p<0.01)$ and region $(F(2,74)=12.59, p<0.01)$. Specifically, we observed an overall decrease in PV cell count as a function of age between 1- and 6-month-old CON groups, such that 6-month-old rats had significantly lower PV cell counts than 1-month-old rats. This age- dependent decrease in PV was seen across all HPC sub-regions: CA1 ( $p$ $<0.01)$, CA3 $(p<0.01)$, and DG $(p<0.05)$.

Chronic KET administration and time of sacrifice as a function of age In CA1 there was a significant Age x Treatment interaction $(F(2$, $84)=5.34, p<0.01)$, and this significant interaction was also observed in CA3 $(F(2,84)=5.89, p<0.01)$ and DG $(F(2,54)=9.99, p<0.001)$. Post-hoc Holm-Sidak's multiple comparisons of simple effects within each age group were conducted to evaluate significant interactions observed in CA1, CA3, and DG. In 1-month-old rats, chronic KET treatment significantly reduced PV cell count in both KET-I and KET-D groups compared to CON in CA1 $(p<0.05), \mathrm{CA} 3(p<0.05)$, and DG ( $p$ $<0.01)$. Notably, there was no effect of tissue collection timeline, evidenced by a lack of difference in PV count between KET-I and KETD groups. See Figure 2 for photomicrographs of HPC regions and Figure 3 for graphical data.

In 6-month-old rats, KET treatment generally did not significantly alter PV cell count within CA1 or CA3. Within the DG, however, posthoc comparisons revealed a significant increase in PV cell count in KET$\mathrm{D}$ rats compared to $\mathrm{CON}(p<0.05)$ and a trending difference between KET-I and CON groups $(p=0.078)$. Additionally, there was an overall observable trend toward an increase in PV cell count between CON and KET-I/KET-D treated groups in both CA1 $(p=0.134)$ and CA3 $(p=$ $0.196)$ regions. Overall, there were no significant differences based on time of tissue collection between KET-I and KET-D groups. See Figures 2 and 3 .

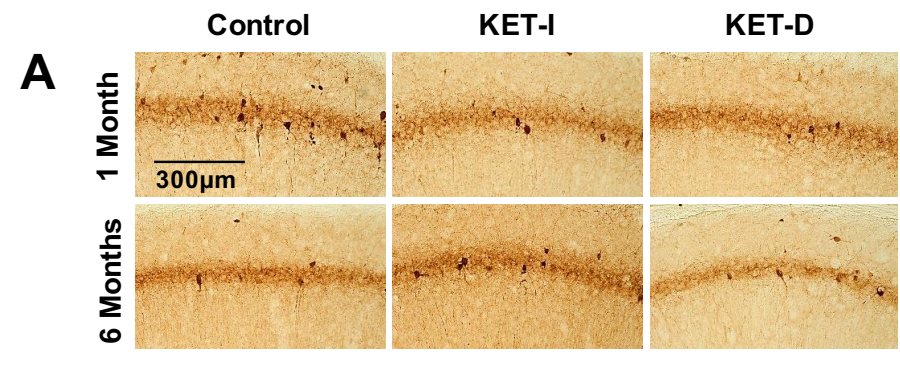

B
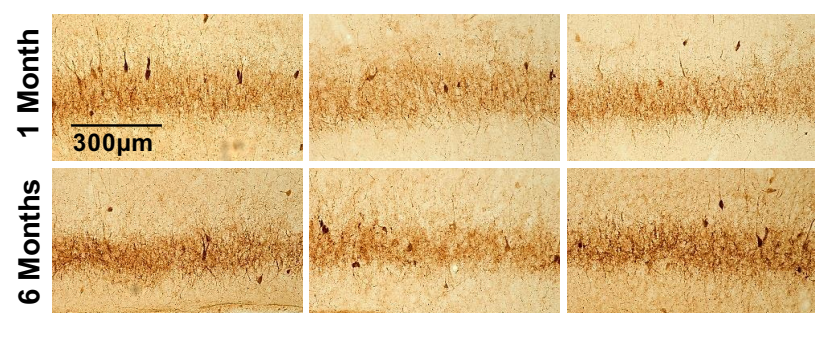

C
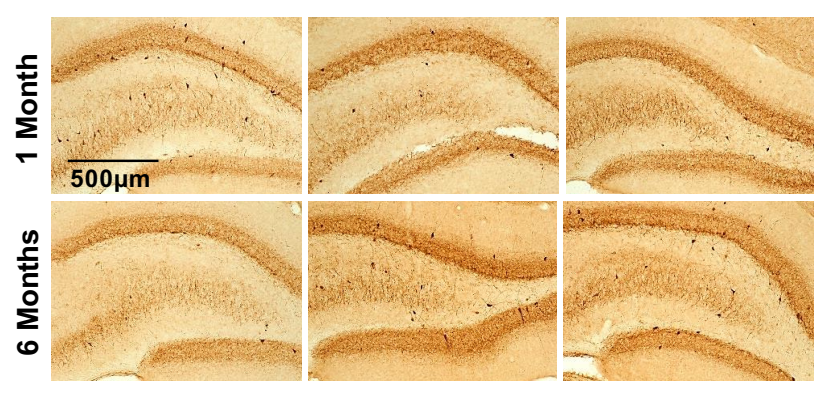

Figure 2. Representative photomicrographs of HPC sub-regions used for analysis in the present study: CA1 (A), CA3 (B), and DG (C) in 1- and 6-month CON, KET-I, and KET-D groups. There was a significant decrease in PV cell count in all sub-regions in 1-month old animals following KET treatment, while 6-month old rats showed a general increase in mean PV cell count following KET treatment (significant increase noted in DG). Time of tissue collection (KET-I v. KET-D) did not significantly impact results. 
bioRxiv preprint doi: https://doi.org/10.1101/399188; this version posted August 23, 2018. The copyright holder for this preprint (which was not certified by peer review) is the author/funder, who has granted bioRxiv a license to display the preprint in perpetuity. It is made available under aCC-BY-NC-ND 4.0 International license.

Honeycutt \& Chrobak, 08.23.2018 - preprint copy - BioRxiv

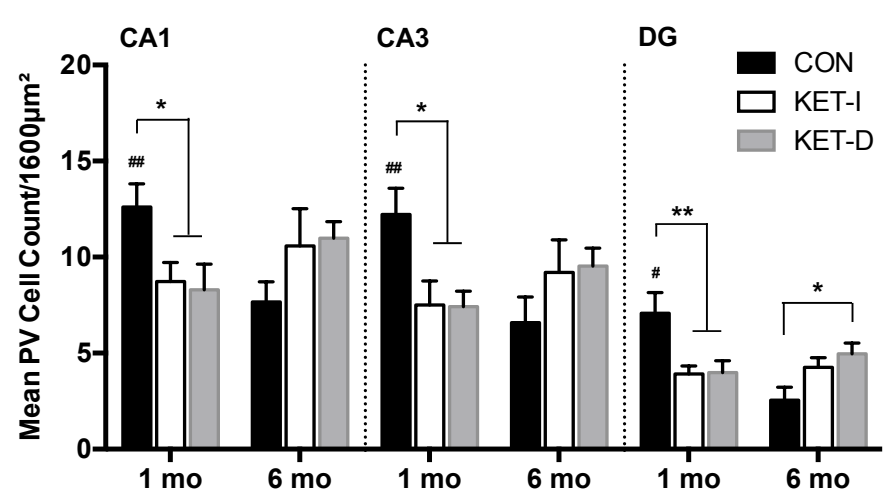

Figure 3. Chronic KET treatment significantly decreased mean PV cell count across all HPC sub-regions (CA1, CA3, DG) exclusively in 1 -month old rats $\left({ }^{*} p<0.05 ;{ }^{* *} p\right.$ $<0.01)$. Conversely, chronic KET treatment in 6-month old rats generally increased mean PV cell count, reaching significance within the DG. Time of tissue collection (KET-I v. KET-D) did not meaningfully impact cell count in any groups. A significant developmentally dependent decrease in mean PV cell count between 1- and 6-month old CON rats was seen across all HPC sub-regions. Significant differences between CON groups in each sub-region are indicated with a \# $(p<0.05)$ or \#\# $(p<0.01)$.

\section{Neocortical findings}

Within the retrosplenial cortex (Figure 4A), there was no main effect of age $(F(1,24)=0.26, p=0.61)$, or treatment $(F(1,24)=0.88, p=0.43)$. Similarly, there was no main effect of age $(F(1,24)=2.78, p=0.11)$ or treatment $(F(1,24)=0.86, p=0.44)$ in the somatosensory barrel fields

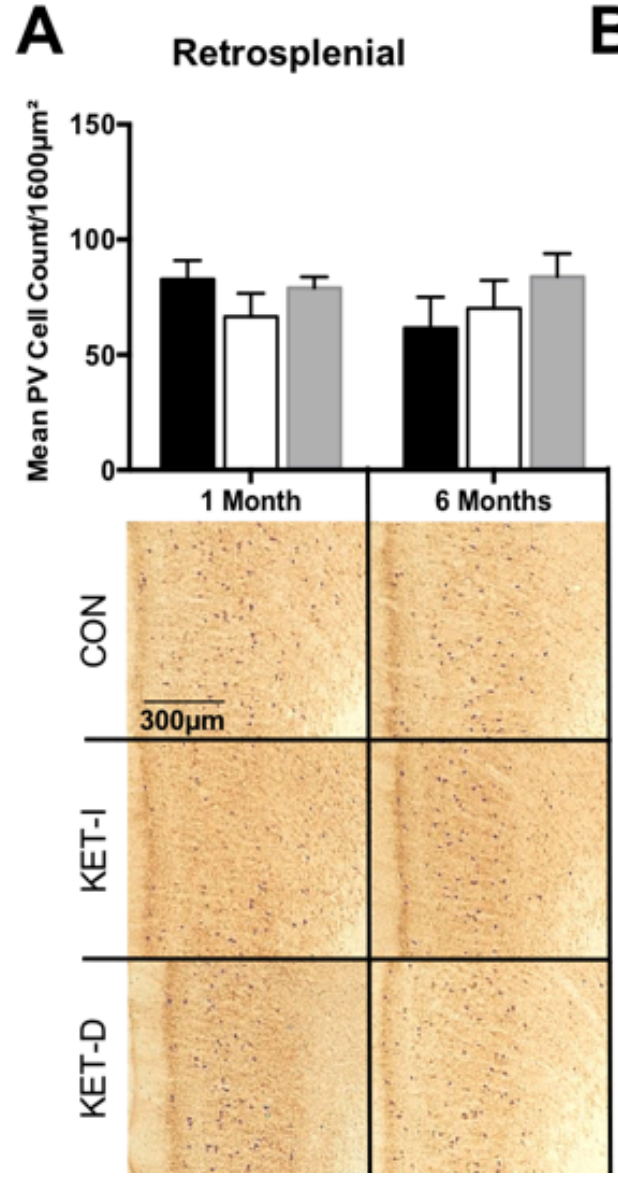

B

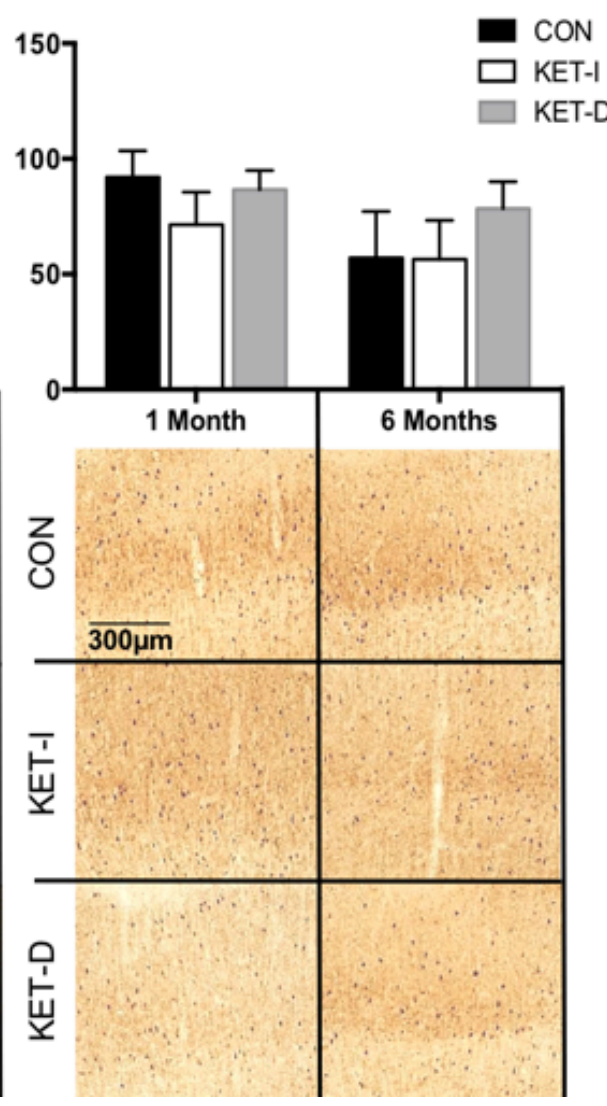

(Figure 4B). In addition, neither cortical region (retrosplenial nor somatosensory) showed an interaction effect between the two factors ( $p$ $=0.37$ and 0.63 , respectively). Representative photomicrographs can be seen in Figure 4A-B.

\section{Discussion}

The present work supports previous studies detailing a developmentally-dependent normative decrease in PV cell count within all sub-regions of the HPC (CA1, CA3, DG), but not within adjacent cortical regions in control rats (Honeycutt et al., 2016). Importantly, this work is the first to detail a novel dissociation between the effects of chronic KET administration on PV cell count based on age of treatment and anatomical region, without regard to time of tissue collection. Here, we discuss the main findings observed, including: 1) age as a significant factor in normative PV cell count within the HPC, a key brain region related to schizophrenia; and 2) the differential modulation of chronic sub-anesthetic KET administration on PV cell count as a function of developmental age.

\section{Age significantly impacts normative PV counts}

Overall, there was a main effect of age in CON rats, such that 1month-old rats had significantly higher PV cell counts within the HPC than 6-month-old CON rats. Notably, these findings detail a marked (up to approx. 50\%) decrease in PV across all three HPC sub-regions (CA1, CA3, and DG) from 1 to 6-month CON animals, with the most dramatic age-related decrease observed in DG. This, in conjunction with prior reports of age-dependent decreases from our lab (Honeycutt et al., 2016) and others (Lolova and Davidoff, 1992; Miettinen et al., 1993; Vela et al., 2003; Lee et al., 2013), provide evidence for natural alterations in PV phenotype across development in a region-specific manner. Importantly, the present findings provide clarity to this body of work, as the rats in this study were behaviorally naïve, whereas many studies employ behavioral assays on their subjects that may alter baseline PV due to enrichment effects of training (e.g., Iuvone et al., 1996; Komitova et al., 2013). These robust changes in PV cell count, as a function of age, should be thoroughly considered, as differences in baseline counts can interfere with experimental manipulations, leading to lack of validity as well as difficulty in interpretation and generalization of results.

\section{Chronic KET treatment differentially impacts $P V$ cell count as a function of age and region}

The present work reveals that chronic KET administration selectively altered PV cell count within the HPC but did not significantly change the number of PV+ cells within the neocortical areas examined in either 1- or 6-month old rats, nor did time of sacrifice. Importantly, the present findings indicate a differential and opposite role of chronic KET treatment on PV cell count that is age-dependent within the HPC.

Figure 4. Representative photomicrographs and results of cortical analyses. Retrosplenial (A) and Somatosensory Barrel Field (B) cortices did not show changes in PV cell count as a function of age. Furthermore, none of the neocortical regions examined showed changes in PV cell count following KET administration in either KET-I or KET-D groups. Representative photomicrographs of these cortical data can be seen below the 
Honeycutt \& Chrobak, 08.23.2018 - preprint copy - BioRxiv

We present robust evidence for a decrease in PV cell counts within 1month-old KET treated rats compared to age-matched CON, which is in agreement with previous work (e.g., Kittelberger et al., 2012). The reduction in PV cell count is nearly $30 \%$ in KET treated groups across all HPC sub-regions, and remains consistent regardless of time of sacrifice, indicating a long-term sustained effect of chronic KET treatment on underlying neuropathology. Conversely, we also describe an opposite effect in 6-month-old KET treated rats, such that those treated show a general increase in PV cell counts compared to their age-matched CON counterparts. The observation of a significant reduction in PV cell count in 1- vs. 6-month-old rats suggests that KET may be interacting with PV expressing neurons in different ways based on age and age-related changes in PV-localized NMDA receptors (Cull-Candy et al., 2001). This dissociation likely also speaks to the developmental switch in NMDA receptor subunit composition, which has been long theorized to be a contributing factor to the delayed onset of schizophrenia symptoms in late adolescence/early adulthood (Law et al., 2003).

In addition to its blockade of NMDA receptors, it should be noted that KET has a wide range of molecular targets, particularly within brain regions (i.e. HPC) necessary for cognitive function (Sleigh et al., 2014). Indeed, KET also interacts with HCN1 receptors (Chen et al., 2009), and nicotinic acetylcholine receptors (Scheller et al., 1996), with alterations in the function of these receptors implicated in cognitive dysfunction (e.g., Levin, 2012; Luo et al., 2015). KET administration is also linked to alterations in the release and modulatory functions of neurotransmitters such as acetylcholine (Lydic and Baghdoyan, 2002; Nelson et al., 2002) and dopamine (Kamiyama et al., 2011), and has been shown to mediate GABA function (i.e. McNally et al., 2011; Wang et al., 2017). Because PV is expressed exclusively on GABAergic neurons, it is likely that KET-induced alterations in the function of these neurons - via the aforementioned mechanisms - may differentially contribute to the changes seen in PV cells following chronic treatment. As such, additional studies are needed to further elucidate upon which of these pathways lead to measurable changes in PV cell count following KET.

The increase in PV cell count in adult rats described in the present study has not been well documented in the literature, though our findings corroborate reports of an increase in HPC PV (Sabbagh et al., 2013) and cortical PV (Abdul-Monim et al., 2007) cell counts using a similar treatment protocol. Indeed, PV has been shown to be dynamic and impacted through a variety of avenues, including behavioral and/or environmental enrichment experiences (Gomes da Silva et al., 2010; Urakawa et al., 2013; Komitova et al., 2013; Donato et al., 2014; Sun et al., 2016; Sampedro-Piquero et al., 2016), though the mechanism by which KET is having a similar age-dependent impact warrants further investigation. While it is unclear the mechanism by which PV, specifically, can be up- and/or down-regulated, evidence suggests that chronic low-dose KET administration has the capacity to increase neural proliferation and functional maturation within the HPC in adult rats (Soumier et al., 2016). This KET-induced increase in neural proliferation, paired with evidence that progenitor cells are capable of differentiating into PV+ GABAergic well into the postnatal period (Shetty and Hattiangady, 2013), may in part explain/contribute to the increased DG $\mathrm{PV}+$ cells following KET treatment in $6 \mathrm{mo}$ rats observed here. Furthermore, based on these findings, it is reasonable to conclude that KET administration may serve to equalize PV cell count between 1- and 6-month old groups via different developmentally-dependent pathways. This caveat can be extended to previous and future work to highlight the importance of controlling for - and reporting - age of treatment and/or tissue collection to better understand the role of NMDA hypofunction on vulnerable populations of GABAergic neurons implicated in schizophrenia neuropathology. It is also notable to point out the discrepancies in NMDA antagonist dosage and treatment length in previous work, as these likely also significantly contribute to variability across studies (see Table 1). While the present work focused on changes attributable to age and time of post-treatment tissue collection, the field would benefit from future research directly comparing differences in dose and treatment length on PV outcomes.

The present work highlights the importance of considering age when evaluating changes in PV cell count, particularly within the HPC, in rodent models. Specifically, this work reinforces the importance for controlling for this developmental variable when examining KET- and, by extension, NMDA antagonist - oriented models of the neuropathology of schizophrenia. We provide novel evidence indicating that chronic subanesthetic KET-induced changes in PV cell count may be exclusively seen in young rats, and that the timeline of administration is likely crucial to understanding the relationship between PV and KET-induced cognitive and behavioral impairments. To our knowledge, this is the first report of a systematically described differential effect of KET as a function of age - particularly within the HPC - and provides important nuance to the literature describing KET-induced changes in PV. Future studies providing a systematic characterization of the PFC and it subregions in a similar manner would be a worthwhile and substantial expansion of the present work, as alterations in PV in the PFC have been reported in schizophrenia (i.e. Lewis et al., 2012; Dienel and Lewis, 2018). Additional investigation further detailing the impact of chronic pharmacological antagonism of the NMDA receptor on concomitant cognitive-behavioral impairment across age is warranted to understand the role of PV in regulating cognition, and whether these processes may be sensitive to aging.

\section{Acknowledgments}

The authors would like to sincerely thank the hard work of undergraduate research assistants at the University of Connecticut who assisted in the collection of data for the present manuscript, specifically: Kevin M. Keary III and Vanessa M. Kania.

\section{$\underline{\text { References }}$}

Abdul-Monim Z, Neill JC, Reynolds GP (2007) Sub-chronic psychotomimetic phencyclidine induces deficits in reversal learning and alterations in parvalbumin-immunoreactive expression in the rat. J Psychopharmacol 21:198-205.

Adell A, Jiménez-Sánchez L, López-Gil X, Romón T (2012) Is the acute NMDA receptor hypofunction a valid model of schizophrenia? Schizophr Bull 38:9-14.

Beasley CL, Reynolds GP (1997) Parvalbumin-immunoreactive neurons are reduced in the prefrontal cortex of schizophrenics. Schizophr Res 24:349-355.

Behrens MM, Ali SS, Dao DN, Lucero J, Shekhtman G, Quick KL, Dugan LL (2007) Ketamine-induced loss of phenotype of fastspiking interneurons is mediated by NADPH-oxidase. Science 318:1645-1647.

Behrens MM, Ali SS, Dugan LL (2008) Interleukin-6 mediates the increase in NADPH-oxidase in the ketamine model of schizophrenia. J Neurosci 28:13957-13966.

Benes FM, Lange N (2001) Two-dimensional versus three-dimensional cell counting: A practical perspective. Trends Neurosci 24:11-17. 
Benneyworth MA, Roseman AS, Basu AC, Coyle JT (2011) Failure of NMDA receptor hypofunction to induce pathological reduction in PV-positive GABAergic cell markers. Neurosci Lett 488:267-271.

Braun I, Genius J, Grunze H, Bender A, Möller HJ, Rujescu D (2007) Alterations of hippocampal and prefrontal GABAergic interneurons in an animal model of psychosis induced by NMDA receptor antagonism. Schizophr Res 97:254-263.

Chen X, Shu S, Bayliss DA (2009) HCN1 channel subunits are a molecular substrate for hypnotic actions of ketamine. J Neurosci 29(3):600-609.

Coyle JT, Basu A, Benneyworth M, Balu D, Konopaske G (2012) Glutamatergic synaptic dysregulation in schizophrenia: Therapeutic implications. Handb Exp Pharmacol 213:267-295.

Cull-Candy S, Brickley S, Farrant M (2001) NMDA receptor subunits: diversity, development and disease. Curr Opin Neurobiol 11:327335.

de Jong GI, Naber PA, Van der Zee EA, Thompson LT, Disterhoft JF, Luiten PG (1996) Age-related loss of calcium binding proteins in rabbit hippocampus. Neurobiol Aging 17:459-465.

Dienel SJ, Lewis DA (2018) Alterations in cortical interneurons and cognitive function in schizophrenia. Neurobiol Dis https://doi.org/10.1016/j.nbd.2018.06.020

Donato F, Rompani SB, Caroni P (2013) Parvalbumin-expressing basketcell network plasticity induced by experience regulates adult learning. Nature 504:272-276.

Eyles DW, McGrath JJ, Reynolds GP (2002) Neuronal calcium-binding proteins and schizophrenia. Schizophr Res 57:27-34.

Gomes da Silva S, Doná F, da Silva Fernandes MJ, Scorza FA, Cavalheiro EA, Arida RM (2010) Physical exercise during adolescent period of life increases hippocampal parvalbumin expression. Brain Dev 32:137-142.

Gonzalez-Burgos G, Lewis DA (2012) NMDA receptor hypofunction, parvalbumin-positive neurons, and cortical gamma oscillations in schizophrenia. Schizophr Bull 38:950-957.

Guillery RW (2002) On counting and counting errors. J Comp Neurol 447:1-7.

Honeycutt JA, Keary KM, Kania VM, Chrobak JJ (2016) Developmental age differentially mediates the calcium-binding protein parvalbumin in the rat: Evidence for a selective decrease in hippocampal parvalbumin cell counts. Dev Neurosci 38:105-114.

Iuvone L, Geloso MC, Dell'Anna E (1996) Changes in open field behavior, spatial memory, and hippocampal parvalbumin immunoreactivity following enrichment in rats exposed to neonatal anoxia. Exp Neurol 139:25-33.

Jeevakumar V, Driskill C, Paine A, Sobhanian M, Vakil H, Morris B, Ramos J, Kroener S (2015) Ketamine administration during the second postnatal week induces enduring schizophrenia-like behavioral symptoms and reduces parvalbumin expression in the medial prefrontal cortex of adult mice. Behav Brain Res 282:165175.

Jenkins TA, Harte MK, Reynolds GP (2010) Effect of subchronic phencyclidine administration on sucrose preference and hippocampal parvalbumin immunoreactivity in the rat. Neurosci Lett 471:144-147.

Kamiyama H, Matsumoto M, Otani S, Kimura SI, Shimamura KI, Ishiwaka S, Yanagawa Y, Togashi H (2011) Mechanisms underlying ketamine-induced synaptic depression in rat hippocampus-medial prefront cortex pathway. Neuroscience 177:159-169.

Keilhoff G, Becker A, Grecksch G, Wolf G, Bernstein HG (2004a) Repeated application of ketamine to rats induces changes in the hippocampal expression of parvalbumin, neuronal nitric oxide synthase and cFOS similar to those found in human schizophrenia. Neuroscience 126:591-598.

Keilhoff G, Bernstein HG, Becker A, Grecksch G, Wolf G (2004b) Increased neurogenesis in a rat ketamine model of schizophrenia. Biol Psychiatry 56:317-322.

Kittelberger K, Hur EE, Sazegar S, Keshavan V, Kocsis B (2012) Comparison of the effects of acute and chronic administration of ketamine on hippocampal oscillations: relevance for the NMDA receptor hypofunction model of schizophrenia. Brain Struct Funct 217:395-409.

Koh MT, Shao Y, Sherwood A, Smith DR (2016) Impaired hippocampaldependent memory and reduced parvalbumin-positive interneurons in a ketamine mouse model of schizophrenia. Schizophr Res 171:187-194.

Komitova M, Xenos D, Salmaso N, Tran KM, Brand T, Schwartz ML, Ment L, Vaccarino FM (2013) Hypoxia-induced developmental delays of inhibitory interneurons are reversed by environmental enrichment in the postnatal mouse forebrain. J Neurosci 33:1337513387.

Law,AJ, Weickert CS, Webster MJ, Herman MJ, Herman MM, Kleinman JE, Harrison PJ (2003) Expression of NMDA receptor NR1, NR2A and NR2B subunit mRNAs during development of the human hippocampal formation. Eur J Neurosci 18:1197-1205.

Lee YJ, Yan BC, Park JH, Ahn JH, Kim IH, Lee JC, Lee HY, Kim YM, et al. (2013) Differences of calcium binding proteins immunnoreactivities in the young hippocampal CA1 region from the adult following transient ischemic damage. J Neurol Sci 326:40-47.

Levin ED (2012) $\alpha 7$-nicotinic receptors and cognition. Curr Drug Targets 13(5):602-606.

Lewis DA, Curley AA, Glausier JR, Volk DW (2012) Cortical parvalbumin interneurons and cognitive dysfunction in schizophrenia. Trends Neurosci 35:57-67.

Lolova I, Davidoff M (1992) Age-related morphological and morphometrical changes in parvalbumin- and calbindinimmunoreactive neurons in the rat hippocampal formation. Mech Ageing Dev 66:195-211.

Luo P, Lu Y, Li C, Zhou M, Chen C, Lu Q, Xu X, He Z, Guo L (2015) Long-lasting spatial learning and memory impairments caused by chronic cerebral hypoperfusion associated with a dynamic change of $\mathrm{HCN} 1 / \mathrm{HCN} 2$ expression in hippocampal CA1 region. Neurobiol Learn Mem 123:72-83.

Lydic R, Baghdoyan HA (2002) Ketamine and MK-801 decrease acetylcholine release in the pontine reticular formation, slow breathing, and disrupt sleep. Sleep 25(6):617-622.

McNally JM, McCarley RW, McKenna JT, Yanagawa Y, Brown RE (2011) Complex receotir mediation of acute ketamine application on in vitro gamma oscillations in mouse prefrontal cortex: modeling gamma band oscillation abnormalities in schizophrenia. Neuroscience 199:51-63.

Meltzer HY, Horiguchi M, Massey BW (2011) The role of serotonin in the NMDA receptor antagonist models of psychosis and cognitive impairment. Psychopharmacol (Berl) 213:289-305.

Meltzer HY, Rajagopal L, Huang M, Oyamada Y, Kwon S, Horiguchi M (2013) Translating the N-methyl-D-aspartate receptor antagonist model of schizophrenia to treatments for cognitive impairment in schizophrenia. Int J Neuropsychopharmacol 16:2181-2194.

Miettinen R, Sirviö J, Riekkinen P Sr, Laakso MP, Riekkinen M, Riekkinen P Jr (1993) Neocortical, hippocampal and septal parvalbumin- and somatostatin-containing neurons in young and aged rats: correlation with passive avoidance and water maze performance. Neuroscience 53:367-378. 
Honeycutt \& Chrobak, 08.23.2018 - preprint copy - BioRxiv

Nelson CL, Burk JA, Bruno JP, Sarter M (2002) Effects of acute and repeated systemic administration of ketamine on prefrontal acetylcholine release and sustained attention performance in rats. Psychopharmacology (Berl) 161(2):168-179.

Nomura T, Fukuda T, Aika Y, Heizmann CW, Emson PC, Kobayashi T, Kosaka T (1997) Distribution of nonprincipal neurons in the rat hippocampus, with special reference to their dorsoventral difference. Brain Res 751:64-80.

Paxinos G, Watson C 1997) The Rat Brain in Stereotaxic Coordinates. New York: Academic Press.

Reynolds GP, Abdul-Monim Z, Neill JC, Zhang ZJ (2004) Calcium binding protein markers of GABA deficits in schizophrenia postmortem studies and animal models. Neurotox Res 6:57-61.

Rómon T, Mengod G, Adell A (2011) Expression of parvalbumin and glutamic acid decarboxylase-67 after acute administration of MK801. Implications for the NMDA hypofunction model of schizophrenia. Psychopharmacology (Berl) 217: 231-238.

Rujescu D, Bender A, Keck M, Hartmann AM, Ohl F, Raeder H, Giegling I, Genius J, et al. (2005) A pharmacological model for psychosis based on N-methyl-D-aspartate receptor hypofunction: Molecular, cellular, functional and behavioral abnormalities. $\mathbf{J}$ Biopsych 59:721-729.

Sabbagh JJ, Murtishaw AS, Bolton MM, Heaney CF, Langhardt M, Kinney JW (2013) Chronic ketamine produces altered distribution of parvalbumin-positive cells in the hippocampus of adult rats. Neurosci Lett 550:69-74.

Sampedro-Piquero P, Castilla-Ortega E, Zancada-Menendez C, Santín LJ, Begega A (2016) Environmental enrichment as a therapeutic avenue for anxiety in aged Wistar rats: Effect on cat odor exposition and GABAergic interneurons. Neuroscience 330:17-25.

Scheller M, Bufler J, Hertle I, Schneck HJ, Franke C, Kochs E (1996) Ketamine blocks currents through mammalian nicotinic acetylcholine receptor channels by interaction with both the open and the closed state. Anesth Analg 83(4):830-836.

Schobel SA, Chaudhury NH, Khan UA, Paniagua B, Styner MA, Asllani I, Inbar BP, Corcoran CM, et al. (2013) Imaging patients with psychosis and a mouse model establishes a spreading pattern of hippocampal dysfunction and implicates glutamate as a driver. Neuron 78:81-93.
Shetty AK, Hattiangady B (2013) Postnatal age governs the extent of differentiation of hippocampal CA1 and CA3 subfield neural stem/progenitor cells into neurons and oligodendrocytes. Int $\mathbf{J}$ Neurosci 31(7):646-656.

Sleigh J, Harvey M, Voss L, Denny B (2014) Ketamine - more mechanisms of action than just NMDA blockade. Trends in Anesthesia and Critical Care 4:76-81.

Soumier A, Carter RM, Schoenfeld TJ, Cameron HA (2016) New hippocampal neurons mature rapidly in response to ketamine but are not required for its acute antidepressant effects on neophagia in rats. eNeuro 3(2) DOI: 10.1523/ENEURO.0116-15.2016.

Sun XR, Zhang H, Zhao HT, Ji MH, Li HH, Wu J, Li KY, Yang JJ (2016) Amelioration of oxidative stress-induced phenotype loss of parvalbumin interneurons might contribute to the beneficial effects of environmental enrichment in a rat model of post-traumatic stress disorder. Behav Brain Res 312:84-92.

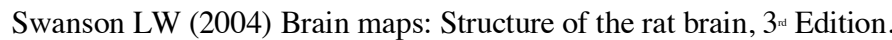

Urakawa S, Takamoto K, Hori E, Sakai N, Ono T, Nishijo H (2013) Rearing in enriched environment increases parvalbumin-positive small neurons in the amygdala and decreases anxiety-like behavior of male rats. BMC Neurosci 14:13.

Vela J, Gutierrez A, Vitorica J, Ruano D (2003) Rat hippocampal GABAergic molecular markers are differentially affected by ageing. J Neurochem 85:368-377.

Wang CZ, Yang SF, Xia Y, Johnson KM (2008) Postnatal phencyclidine administration selectively reduces adult cortical parvalbumincontaining interneurons. Neuropsychopharmacology 33:2442-2455.

Wang D-S, Penna A, Orser BA (2017) Ketmaine increases the function of $\gamma$-Aminobutyric acid type A receptors in hippocampal and cortical neurons. Anesthesiology 126:666-677.

Zhang ZJ, Reynolds GP (2002) A selective decrease in the relative density of parvalbumin immunoreactive neurons in the hippocampus in schizophrenia. Schizophr Res 55:1-10.

Zhang Y. Behrens MM, Lisman JE (2008) Prolonged exposure to NMDAR antagonist suppresses inhibitory synaptic transmission in prefrontal cortex. J Neurophysiol 100:959-965. 